\title{
Physical Punishment of Children
}

\section{Time to End the Defence of Reasonable Chastisement in the UK, USA and Australia}

\section{Andrew Rowland FRCPCH FRCEM FRSA}

Honorary Professor, The University of Salford, UK; Consultant in Paediatric Emergency Medicine, The Pennine Acute Hospitals NHs Trust, uk; Churchill Fellow, The Winston Churchill Memorial Trust, Uk; Board Member, M'Lop

Tapang, Cambodia

andrew.rowland@pat.nhs.uk

\section{Felicity Gerry QC}

Queen's Counsel in London, Leeds and Darwin; Chair of the Research and Research Training Committee, Charles Darwin University;

Member of the Research group on Fundamental Rights and Constitutionalism at the Vrije Universiteit Brussel

felicity.gerry@cdu.edu.au

\section{Marcia Stanton MSW}

Senior Injury Prevention Specialist, Phoenix Children's Hospital; Founder and Chair, Arizona Adverse Childhood Experiences (ACEs) Consortium mstanto@phoenixchildrens.com

\section{It is easier to build strong children than to repair broken men} FREDERICK DOUGLASS, 1817-1895

\footnotetext{
Abstract

As at March 2016, 49 states had reformed their laws to clearly prohibit all corporal punishment of children (United Nations 1989) in all settings, including the home 
(Global Initiative to End All Corporal Punishment of Children, n.d.) By January 2017 this number had reached 52 . As the trend moves towards abolition, it is not an acceptable position for the United Kingdom (UK), the United States of America (USA) and Australia (Poulsen, 2015) to remain missing from that list. Whilst they are, effectively, a child (a person aged under 18 years of age), is the only person in all three countries that it is legal to hit. This article seeks to restate arguments in this area in a simple way to restart the debate in a modern context where understanding of child abuse is perhaps more widespread than it ever was in the past. On 20 October 2014 a report, Living on a Railway Line, was launched in the U K to mark the $25^{\text {th }}$ anniversary of the signing of the UN Convention on the Rights of the Child, which took place on 20 November 1989 (Rowland, 2014). It recommended removing the defence of reasonable chastisement in relation to the punishment of children. This article seeks to build on that agenda in a comparative context taking a three way perspective from the UK, the USA and Australia. It concludes that moves to prevent family violence are progressive but the position of a society where physical punishment of children is permitted yet child abuse is forbidden is not a tenable one. Reducing the number of cases of child abuse must begin with a clear message from society that physical punishment of children, whatever the circumstances, is unacceptable. The situation is serious enough to introduce aspirational legislation to remove justifications for physical punishment of children with the aim of modifying behaviour within society.

\section{Keywords}

child punishment - child assault - child abuse - corporal punishment - reasonable chastisement - child rights

\section{Introduction}

As at March 2016, 49 states had reformed their laws to clearly prohibit all corporal punishment of children (United Nations, 1989) in all settings, including the home (Global Initiative to End All Corporal Punishment of Children, n.d.). By January 2017 this number had reached $5^{2}$. As the trend moves towards abolition, it is not an acceptable position for the United Kingdom (UK), the United States of America (USA) and Australia (Poulsen, 2015) to remain missing from that list. Whilst they are, effectively, a child (a person aged under 18 years of age) is the only person in all three countries that it is legal to hit. This article seeks to restate arguments in this area in a simple way to restart the debate in 
a modern context where understanding of child abuse is perhaps more widespread than it ever was in the past.

On 20 October 2014 a report, Living on a Railway Line, was launched in the UK to mark the $25^{\text {th }}$ anniversary of the signing of the UN Convention on the Rights of the Child, which took place on 20 November 1989 (Rowland, 2014). It recommended removing the defence of reasonable chastisement in relation to the punishment of children. This article seeks to build on that agenda in a comparative context taking a three way perspective from the UK, the USA and Australia. Physical abuse can occur in any family, but it is more likely to happen in families that are vulnerable to certain risks, such as domestic (inter-partner) violence, substance misuse and adverse mental health. Child maltreatment has potentially severe and long-lasting impacts on children affecting all aspects of their lives. Although there has been progress over the last quarter of a century there are still laws, policies and procedures which fall way short of properly protecting children as was agreed by the signatories to the Convention 25 years ago. Here we focus on what legislative change might be necessary to better protect children, to assist health professionals in recognising children at risk and to encourage attitudinal change in the wider community with the hope of progress towards a better and more supportive environment in which children can grow up safe from physical punishment. Throughout we will use the terms "child maltreatment" and "child abuse" and "neglect" synonymously.

\section{$2 \quad$ Meaning of Punishment}

Child abuse has been identified as falling into four categories of abuse that children may be at risk of, or may have suffered from: neglect, sexual abuse, emotional abuse and physical abuse (HM Government, 2013). Here, whilst recognising that all four may arise in varying degrees in a given case study, we focus on the physical abuse of children.

Physical punishment is the use of physical force with the intention of causing the child to experience bodily pain or discomfort so as to correct or punish the child's behaviour (Bitensky, 2006, Committee on the Rights of the Child, 2006; Straus, 2001). Physical punishment, often used interchangeably with corporal punishment, includes slapping, spanking or smacking and hitting with a hard object - such as a wooden paddle (Human Rights Watch, 2008b). It can also include things such as washing a child's mouth out with soap and water, making a child kneel on sharp or painful objects, forcing a child to sit or stand 
in painful positions for a long period of time or compelling a child to engage in excessive exercise or physical exertion (Pinheiro, 2006).

Physical punishment is, thus, very different from physical restraint - that which may be necessary to protect a child from self-harm or harming others. The language of physical punishment - smack, slap, beat, tap, paddle and hit etc. - reveal that all are forms of violence which, in relation to adult victims, would amount to an assault. Historically the justification was that children needed to learn discipline or to be punished for misdeeds. However, the motivation behind the physical punishment cannot reduce the hurtful impact that it has on the child (Royal College of Paediatrics and Child Health, 2009).

3

History

In New York, United States of America in 1874, a young girl called Mary Ellen was systematically abused by her adoptive parent, Mary Connolly. The abuse was well known but complaints to the police brought no action as there was no specific law at that time to protect children. Henry Bergh, who had founded the American Society for the Prevention of Cruelty to Animals in 1866, intervened at the request of a local resident, Mrs Etta Wheeler, who wished to rescue Mary Ellen. With use of habeas corpus (a legal principle ensuring that a prisoner can be released from unlawful detention - that is, detention lacking sufficient cause or evidence) Henry Bergh applied, via the Attorney of the American Society for the Prevention of Cruelty to Animals, to the Court and successfully secured the release of Mary Ellen. A prosecution ensued, which resulted in Mary Connolly being sentenced to one year's hard labour in the penitentiary. The pain and suffering behind Mary's statement to the Court in April 1874 requires no further comment:

My name is Mary Ellen. I don't know how old I am. My mother and father are both dead. I call Mrs C momma. I have never had but one pair of shoes, but can't recollect when that was. I have no shoes or stockings this winter. I have never been allowed to go out ... except in the night time, and only in the yard [to use the outdoor privy]. My bed at night is only a piece of carpet stretched on the floor underneath a window and I sleep in my little undergarment with a quilt over me. I am never allowed to play with other children. Momma has been in the habit of whipping me almost every day. She used to whip me with a twisted whip - a rawhide. The whip always left black and blue marks on my body. I have now on my head two black and blue marks which were made by momma with 
the whip, and a cut on the left side of my forehead which was made by a pair of scissors in momma's hand. She struck me with the scissors and cut me. I have no recollection of ever having been kissed and I have never been kissed by momma. I have never been taken on momma's lap or caressed or petted. I never dared speak to anybody, because if I did I would get whipped. I have never had ... any more clothing than I have on at present ... I have seen stockings and other clothes in our room, but I am not allowed to put them on. Whenever momma went out, I was locked up in the bedroom ... I don't know for what I was whipped. Momma never said anything when she whipped me. I do not want to go back to live with momma because she beats me so (American Humane Association, n.d.).

In 1874 the Society for the Prevention of Cruelty to Children was founded and the rights of children to be protected from such horrendous abuse became to be recognised in the USA. Mary Ellen was placed into a new home, married, raised a family of her own and died in 1956 (The New York Society for the Prevention of Cruelty to Children, n.d.). It was not until 1962, following the publication of Dr C. Henry Kempe's seminal paper on child abuse (Kempe et al., 1984), that the public, in the USA at least, started to become aware of the impact of child abuse on a wide scale. Many decades later, child abuse is still a significant issue. Slowly the legal landscape moved from "no protection" to "protection from unreasonable punishment". Now it is moving towards full protection from violence and abuse.

\section{$4 \quad$ Statistics $-\mathrm{UK}$}

Each year in the UK, of those children physically abused (NSPCC, n.d.a):

- 379,000 are injured;

- 70,00o require medical attention;

- 2,800 are taken to Accident and Emergency Departments (EDs).

In the UK, Home Office figures (Office for National Statistics, 2014) show that in 2012/2013 there were $55^{1}$ homicides (murder, manslaughter and infanticide) recorded in England and Wales (an increase of 4 per cent on the 2011/2012 figures). This increase was driven by an increase among those aged under 16 years of age from 47 in 2011/2012 to 67 in 2012/2013 (6o per cent of whom were killed by a parent or step-parent). In 2012/2013, as in previous years, children 
aged under one had the highest victimisation rate of 30 offences per million population.

In the UK The National Society for the Prevention of Cruelty to Children (NSPCC) has found that 18.6 per cent of 11-17 year olds have been severely maltreated by a parent or guardian at some point in their lives and that one in 20 (4.8 per cent) of children have experienced contact sexual abuse but most incidents are not reported to the police and only 3 per cent of adults feel confident about spotting the signs of potential sexual abuse. One in 14 (6.9 per cent) children aged 11-17 years has experienced severe physical violence at the hands of an adult. Looking at findings from 18-24 year olds allows comparison with other research studies that have asked adults about their childhood experiences. The NSPCC found that 25.3 per cent of young adults were severely maltreated during childhood and that 23.7 per cent were exposed to domestic (inter-partner) violence in their homes during childhood (Radford et al., 2011).

Statistics - USA

In 2014 in the USA, state and local child protective services (CPS) received an estimated 3.6 million referrals of children suspected of being abused or neglected. Of these referrals, CPS estimated that 702,000 children (9.4 per 1000) were victims of maltreatment (us Department of Health and Human Services, 2016). Of the child victims, 75 per cent were victims of neglect; 17 per cent of physical abuse; 8.3 per cent of sexual abuse and 15 per cent of other types of maltreatment including emotional abuse, threatened abuse, parental drug or alcohol use or lack of supervision. CPS reports of child maltreatment may underestimate the true occurrence: a non CPS study estimated that 1 in 4 children from the USA experience some form of child maltreatment in their lifetime (Finkelhor et al., 2013). In 2014, an estimated 1,580 children died from child maltreatment (2.13 per 100,000 children) of whom 72.3 per cent experienced neglect and 41.3 per cent experienced physical abuse either exclusively or in combination with another form of maltreatment. Of those 1,580 children who died in 2014 from maltreatment, 70.7 per cent were aged younger than three years.

Figures from the Australian Institute of Health and Welfare (AIHW) Report, Child Protection Australia, indicate that during 2012-13, there were 184,216 
Australian children suspected of being harmed or at risk of harm from abuse and/or neglect (Australian Institute of Health and Welfare, 2014). At a state level, compared to 2011-12 notifications, all jurisdictions have increased notifications, investigations and substantiations except Queensland, which showed a small decrease of less than 1 per cent. The proportional increase for other jurisdictions ranged from less than 1 per cent for Tasmania to 25 per cent in Northern Territory. The Australian Government summary of the data observes that whilst these numbers may reflect an actual change in the magnitude of child maltreatment in Australia, it is also possible that the numbers of notifications may reflect changes in legislation, public awareness, and/or child protection process enquiries (Australian Institute of Family Studies, 2016).

In 2012-13, of the total number of notifications $(272,980), 122,496$ cases (involving 91,370 children) of child abuse were investigated. Of these investigations, 113,341 (93 per cent) were finalised by 31 August 2013 and 53,666 cases were substantiated. Across the jurisdictions, all states and territories had increased substantiations from 2011-12, except for the Australian Capital Territory and the Northern Territory. Substantiations were categorised into one of four harm types: emotional abuse, neglect, physical abuse and sexual abuse. The percentage breakdown was depicted in the report in figure 1. 20 per cent of substantiations of harm/risk of harm related to physical abuse. That is nearly 11,000 children who were the subject of substantiated notifications.

Australia had the $9^{\text {th }}$ lowest rate of child death resulting from maltreatment for children under 15 years of age in the five-year period from 1994-98. While Australia's rate, 0.8 per 100,000 children, is approximately four times the rate in Spain, Greece and Italy, it is below the rates in New Zealand (1.3) and the USA (2.4) (Australian Institute of Family Studies, 2014).

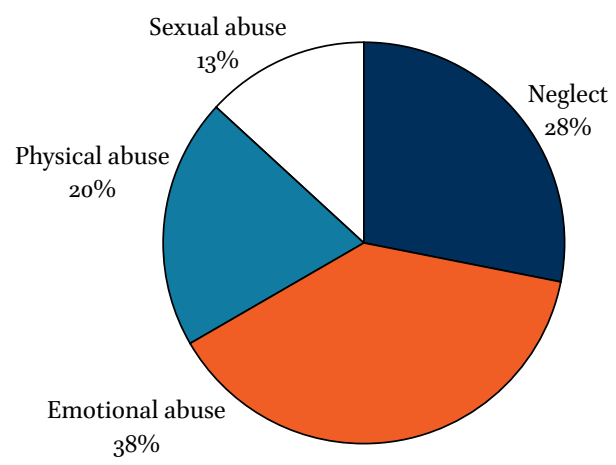

FIGURE 1 Percentage breakdown of primary substantiated harm types in Australia in 2012-13 SOURCE: AUSTRALIAN INSTITUTE OF FAMILY STUDIES (2014, P. 19) 
The practice of hitting children as part of discipline is deeply embedded in cultural views, government law and social policy. Indeed this is also apparent from some religious texts including the Bible, 'He that spareth his rod hateth his son: but he that loveth him chasteneth him betimes' (Book of Proverbs). Some proponents of corporal punishment of children believe that physical punishment of children is thought to teach respect for authority and failure to physically punish them leads to uncontrolled, disrespectful, acting-out behaviour. This implies that lack of sufficient discipline increases the level of societal discord and violence (Benjet and Kazdin, 2003).

Not everyone agrees that corporal punishment of children is inherently wrong with views being expressed that parents need to be empowered with more effective alternatives, not disempowered by premature bans on traditional disciplinary tactics (Larzelere, 2000), that occasional smacking does no harm (Hain, 200o) and that although the harmful effects of physical abuse and other extreme punishments are clear, a blanket injunction against spanking is not justified (Baumrind et al., 2012).

Research conducted on behalf of the Singapore Children's Society looking at public attitudes to actions suggesting child abuse or neglect found that whilst respondents considered sexual abuse to be the most serious form of abuse they were less concerned with emotional maltreatment than other types of abuse. In relation to physical punishment of children, caning was stated to be a widely accepted form of physical punishment and was regarded by the fewest respondents to be "never acceptable" or "abuse/neglect" (Kiong et al., 1996).

Physicians' attitudes are important in this area as these clinicians may be asked to assess children for evidence of physical abuse and part of the history that will be taken from the caregivers ought to relate to disciplinary measures used with the children. In a study assessing physicians' attitudes towards corporal punishment in childhood and their subsequent actions regarding the reporting of child abuse, corporal punishment was approved by $5^{8}$ per cent of physicians and was perceived as an acceptable disciplinary act by a significant proportion of physicians responsible for the healthcare of children.

Support for corporal punishment of children has also come from within judicial circles with one Justice of the Peace in Montgomery County, Texas ordering an 11-year old child to be spanked, with a wooden paddle, in his Courtroom in 2001 (Rice, 2001a). The 11-year old child, who was in foster care and was sent to Court for misbehaviour at school, is reported to have been bent over a table in the Courtroom and struck three times with a paddle. Defending his sentence, the Justice of the Peace is reported to have said, 
He doesn't understand any other punishment but corporal punishment. That was the way I was raised and you were raised and we were much better kids than the current generation. He was using profanity real bad. I said what he needs is corporal punishment.

RICE, 2001B

People who are anti-corporal punishment of children will surely find this punishment of an 11-year old child in foster care, or indeed any child no matter what the care status, to be abhorrent. Even such an appalling story has not moved the U.s. Administration to address the legal and human rights issues.

In a debate about smacking, one parent, who was smacked as a child by his mother and by a number of teachers at primary and secondary school, said,

I believe that the use of smacking, within the context of a loving relationship, is an effective means of discipline. I do not accept the argument that smacking inevitably escalates to child abuse ... I worry about parents who have never smacked a child, and have perhaps never really given it any thought, but then in the heat of the moment lose their temper and really lash out at the child. Hitting a child in anger - smacking a child in anger is wrong .

WHITING et al., 2004: 28

Those who report experiencing more corporal punishment during childhood but also more parental warmth/support hold more favourable attitudes toward spanking and those who report experiencing more corporal punishment during childhood and also more parental impulsiveness hold less favourable attitudes (Bell and Romano, 2012).

In a survey of 1,000 adults from Quebec, Canada, a majority of respondents endorsed spanking despite their recognition of potential harm associated with corporal punishment of children. Spanking was the most reported childhood experience and most violence and abuse predictors were significant and positively correlated. Older respondents who were spanked in childhood and who believed that spanking never or seldom results in physical injuries were the most in favour of spanking. On the other hand, respondents who reported more severe physical violence or psychological abuse in childhood were less in favour of spanking (Gagne et al., 2007).

Adolescents' endorsement of parental use of corporal punishment has been examined to elucidate processes underlying the intergenerational transmission of discipline strategies and adolescents' views varied widely. 
Those adolescents who had been spanked by their own mothers were more approving of this discipline method, regardless of the overall frequency, timing or chronicity of physical discipline that they had received. However, there was no correlation amongst adolescents for whom physical maltreatment in early or middle childhood was suspected (Deater-Deckard et al., 2003). Some children seem to accept corporal punishment as a parental right and as part of the parental role (Vlasis-Cicvaric et al., 2007) but others believe that violence is not going to solve anything: all that it will do is to hurt children and cause more problems and that smacking children should not be legal under any circumstances (Whiting et al., 2004).

Effects on children who suffer from abuse and neglect can include:

- accidental injuries;

- lack of self-esteem;

- physical changes to the developing brain and body as a result of trauma and stress;

- mental health issues such as depression and anxiety;

- poor emotional and physical development;

- smoking, drinking alcohol or drug use;

- disruption to education;

- difficulties in forming and maintaining relationships (Global Initiative to End All Corporal Punishment of Children).

The position of the American Academy of Child and Adolescent Psychiatry, in relation to corporal punishment of children, is as follows:

The American Academy of Child and Adolescent Psychiatry does not support the use of corporal punishment as a method of behavior modification. Corporal punishment includes a wide variety of discipline methods that employ pain as a negative reinforcement to modify behavior. Corporal punishment includes, but is not limited to spanking, a method used by 65 per cent of parents of young children in the United States. Ineffective discipline methods, including corporal punishment, risk straining the caregiver/child relationship and exacerbating a child's psychiatric symptoms. Although a majority of parents report using corporal punishment as a behavior modification technique, most would rather use other means for behavioral management and discipline. 
Extensive research demonstrates that although corporal punishment may have a high rate of immediate behavior modification, it is ineffective over time, and is associated with increased aggression and decreased moral internalization of appropriate behavior. Additional negative outcomes associated with corporal punishment are:

- Increased risk for physical abuse

- Learning that aggression is an acceptable method of problem solving

- Experiencing physical and emotional pain, which decreases learning capacity

- Being less likely to learn why a certain behavior or action was wrong

- Behaving out of fear in the future.

When assessing and treating children and families, child and adolescent psychiatrists should provide information to families about the hazards associated with corporal punishment and encourage and assist parents to modify their child's behavior by other methods. To this end, child psychiatrists should know and discuss effective and evidence based methods of behavior management with families (American Academy of Child and Adolescent Psychiatry, 2012).

In the USA, the American Academy of Pediatrics' (AAP) position on spanking and corporal punishment has evolved over the past few years (Committee on Psychosocial Aspects of Child and Family Health, 1998). In relation to a potential link between spanking and mental disorders in children, the AAP have, since 2012, drawn attention (American Academy of Pediatrics, 2012) to work which found that between two and seven percent of mental disorders were attributable to physical punishment of children (Afifi et al., 2012). The position of the AAP in relation to spanking is as follows:

When advising families about discipline strategies, pediatricians should use a comprehensive approach that includes consideration of the parentchild relationship, reinforcement of desired behaviors, and consequences for negative behaviors. Corporal punishment is of limited effectiveness and has potentially deleterious side effects. The American Academy of Pediatrics recommends that parents be encouraged and assisted in the development of methods other than spanking for managing undesired behavior.

Researchers at Cornell University (Cook and Kopko, 2014) have identified, in a policy briefing, that research findings demonstrate that spanking is 
ineffective and harmful to children and they advocate that national leaders, community stakeholders, parent educators, and parents should consider finding ways to discourage spanking as a viable discipline strategy. In addition, they identified that there is increasing support from prominent professional, religious, and human rights organisations to avoid and eliminate spanking practices. However, spanking is still a common and accepted practice in the United States.

Recent research findings have spurred a shift in attitudes about the practice of spanking across many professional, religious, and human rights organisations worldwide. Spanking is increasingly disavowed by professional and community organisations. Very prominent organisations have begun to abandon spanking as a viable practice, and encourage parents to utilise different discipline practices (Cook and Kopko, 2014).

Other national organisations speaking out against spanking of children in the USA include the American Humane Association (2009), the National Association of Pediatric Nurse Practitioners (2011) and the National Association of Social Workers (2015). In addition, prominent religious organisations have also passed resolutions that encourage parents to avoid spanking (People of the United Methodist Church, 2008; General Assembly of the Presbyterian Church, 2012).

It seems incongruous that physical punishment of children in some schools in the USA is still permitted despite many decades of research showing that:

- children who are physically punished are at greater risk of serious injury and physical child abuse;

- physical punishment of children puts them at risk of negative outcomes including mental health problems;

- physical punishment of children makes it more, not less, likely that they will be defiant and aggressive in the future.

However, it has to be recognised that physical punishment of children is used throughout the world as a disciplinary strategy even though it is related to negative outcomes for children regardless of the parental context in which it is used (Gámez-Gauadix et al., 2010). Not all research concludes that there should be a ban on physical punishment of children and it has been reported that verbal abuse is a more important predictor of conduct problems than corporal punishment (Evans et al., 2012).

In Canada the Joint Statement on Physical Punishment of Children and Youth (Durrant et al., 2004) was developed by a national coalition of organisations facilitated by the Children's Hospital of Eastern Ontario (CHEO). Based on an 
extensive review of research the Joint Statement provides an overview of the developmental outcomes associated with the use of physical punishment. It concludes that the evidence is clear and compelling - physical punishment of children and youth plays no useful role in their upbringing and poses only risks to their development and parents should be strongly encouraged to develop alternative and positive approaches to discipline (CHEO, 2012).

It is difficult to find research which fully supports physical punishment of children and although a review of the impact of non-abusive physical punishment of African-American children was inconclusive, it was suggested that it is possible that there are benefits to non-abusive physical punishment of this select group of children (who were involved in the study) but recognised that further longitudinal studies are needed that better assess the multiple confounders that impact the use of discipline, such as socio-economic status, parental education level and exposure to community or domestic (inter-partner) violence (Horn et al., 2004).

Studies have not always shown that corporal punishment is always associated with poor outcomes in certain groups of children (Simons et al, 2013) and it has been reported that the impact of spanking and corporal punishment on the negative outcomes of externalising, internalising behaviours and low cognitive performance may be minimal (Ferguson, 2013).

Research (Gershoff, 2008) has demonstrated that parents are more likely to use physical punishment if:

- they strongly favour it and believe in its effectiveness or were physically punished as children (Bower-Russa et al., 2001);

- they have a cultural background (for example religion, ethnicity, country of origin) that they perceive approves of the use of physical punishment (Barkin et al., 2007; Gershoff et al, 1999);

- they are socially disadvantaged (for example low income, low level of education or living in a socially deprived area) (Giles-Sims et al., 1995);

- they report being frustrated or aggravated with their children on a regular basis (Regalado et al., 2004);

- the child is under the age of five years or the parent is under 30 years of age (Day et al, 1998);

- they are experiencing stress (such as financial hardship, relationship conflict), adverse mental health symptoms or low emotional well-being (Wissow, 2001).

However, the more parents use physical punishment the more aggressive their children become over time. Even when controlling for their initial levels of 
aggression, the frequency or severity with which children experience physical punishment is associated with increased childhood mental health problems and physical punishment is associated with poorer quality parent-child relationships.

Children who are physically punished are at risk of significant harm with those that have been smacked by their parents being seven times more likely to be seriously assaulted (for example punched or kicked) than those who have not been physically punished and 2.3 times more likely to suffer an injury requiring medical attention than those who have not been smacked (Crandall et al., 2006).

There are a number of possible reasons as to why physical punishment is not effective as a disciplinary technique including that:

- it does not teach children why their behaviour was wrong or what they should do instead;

- it teaches children that they should behave in certain ways or risk physical punishment if they do not, rather than teaching them the important, positive reasons for behaving appropriately;

- it indicates to children that it is acceptable to use physical force and aggression against another person;

- it can increase the likelihood of children behaving aggressively themselves in other social interactions;

- it may teach children to link violence with a relationship that is supposed to be built on the foundation of love.

Alternatives to physical punishment of children do exist. For example, the Triple $\mathrm{P}$ - Positive Parenting Program is one great example of an evidence-based, cost effective system of parenting support. Triple P gives parents simple and practical strategies to help them confidently manage their children's behaviour, prevent problems and build strong, healthy relationships. It is currently in use in 25 countries around the world and has been shown to work across cultures, socio-economic groups and in all kinds of family structures (Triple P, n.d.).

So, physical punishment of children is rife, it remains an embedded societal norm but it is no more effective as a long-term strategy for improving behaviour than other approaches (Roberts and Powers, 1990), and reliance on physical punishment makes other disciplinary strategies less effective (Wilson and Lyman, 1982). It is in this context that the continued use of physical punishment of children conflicts with international human rights law. 
Physical punishment of children violates international human rights law which has been developing for nearly a century. In 1924, the League of Nations (LON) adopted the Geneva Convention which was the first international Human Rights document in history specifically to address children's rights. It was re-affirmed in 1934 but it was not legally binding. The United Nations (UN) was founded after World War II and later adopted the Universal Declaration of Human Rights in 1948 followed by the Declaration of the Rights of the Child in 1959. The preamble of the former protects the right to human dignity and the Declaration recognised that 'the child, by reason of his physical and mental immaturity, needs special safeguards and care, including appropriate legal protection, before as well as after birth'. The latter was the basis of the Convention of the Rights of the Child adopted by the UN General Assembly on 20 November 1989. The Convention on the Rights of the Child was entered into force on 2 September 1990. It is now over a quarter of a century since, through ratification, the human rights of children were recognised internationally when the United Nations Convention on the Rights of the Child (UNCRC) was signed by world leaders who committed to giving the protections it contained legal force.

Article 19 of the UNCRC states:

States Parties shall take all appropriate legislative, administrative, social and educational measures to protect children from all forms of physical or mental violence, injury or abuse, neglect or negligent treatment, maltreatment or exploitation, including sexual abuse, while in the care of parent(s), legal guardian(s) or any other person who has the care of the child.

Physical punishment of children is clearly counter to the UNCRC which confers absolute protection for children against violence while in the care of parent(s), guardian(s) or any other person. That this Convention has almost universal ratification is a testament to the importance placed on children's rights worldwide. Accompanying the Convention are two optional protocols, one on children in armed conflict and one on the sale of children, child prostitution and child pornography (sic).

It would be far more appropriate to use the term "child abuse and exploitation online" instead of child pornography. INTERPOL's approach is that a sexual image of a child should not be described as "pornography", as such 
activities are not consensual sexual acts; instead, they are documented evidence of a crime in progress and are, therefore, abusive and exploitative in nature. The term "Child Abuse Material (CAM) offending" is more appropriate and is therefore used (INTERPOL, n.d.).

In 2006 the Committee on the Rights of the Child, the international body charged with monitoring compliance with the UNCRC, found that article 19 'does not leave room for any level of legalized violence against children'. Whilst the United States is one of only two countries not to have ratified the treaty, it is a signatory and the general view is that the treaty's provisions should be treated as authoritative guidance (Human Rights Watch, 2008a). However, it remains deeply worrying that the USA has neither ratified the treaty nor has it adopted the two optional protocols (Lee and Svevo-Cianci, 2009).

The three countries which are the topic of this paper, USA, Australia and the UK, have each signed and ratified the Convention against Torture and Other Cruel, Inhuman, or Degrading Treatment or Punishment (Convention against Torture) and the International Covenant on Civil and Political Rights (ICCPR). Each of these treaties prohibits the use of cruel, inhuman, or degrading treatment or punishment. Article 7 of the ICCPR states that ' $[\mathrm{n}] \mathrm{o}$ one shall be subjected to ... cruel, inhuman or degrading treatment or punishment'. The Human Rights Committee (HRC), has concluded that the scope of obligations under article 7 'must extend to corporal punishment, including excessive chastisement ordered ... as an educative or disciplinary measure'. Article 16, ICC PR obliges the signatories to undertake to prevent acts of cruel, inhuman or degrading treatment or punishment and Article 9 states that ' $[\mathrm{e}]$ veryone has the right to liberty and security of person'. In addition, Article 5(b) of the International Convention on the Elimination of All Forms of Racial Discrimination (ICERD), to which the UK, Australia and the USA are also party, provides for non-discrimination in the enjoyment of 'the right to security of person and protection by the State against violence or bodily harm'.

Nonetheless corporal punishment continues in USA schools, leaving the distinct inference that if children in the USA can be subjected to violent conduct at school despite international condemnation, there is little hope of protection at home. Bitensky (1997-1998) recognised that this is an emotive issue but found convincing evidence that physical punishment is a hidden cruelty. She has argued for the abolition of the use of physical force with the intention of causing a child to experience bodily pain so as to correct, control, or punish the child's behaviour on the basis that it is a form of sub abuse that continues because often the legislation prevents a prosecution. The language of abolition tends to fuel the emotive responses and it is here that we suggest that our 
proposal to remove the defence of reasonable chastisement would be effective in removing the hidden nature of physical punishment of children and then allow for proper health and policy responses along with clear legal guidance on when to prosecute or not.

There are some complexities in a comparative exercise between the USA, the UK and Australia since the enactment of the Human Rights Act in 1998 which effectively imported principles contained in the Human Rights Convention such that there is some divergence in jurisprudence between the three countries we are considering. The burden on the UK falls not just from its ratification of international instruments but also from its European Union (EU) obligations: within Europe the Council of Europe, Parliamentary Assembly Recommendation 1666 (2004) has stated that Council of Europe, 2004):

The Assembly considers that any corporal punishment of children is in breach of their fundamental right to human dignity and physical integrity. The fact that such corporal punishment is still lawful in certain member states violates their equally fundamental right to the same legal protection as adults. Striking a human being is prohibited in European society and children are human beings. The social and legal acceptance of corporal punishment of children must be ended.

In the UK parents have not been explicitly prohibited from smacking their children. However, section 58 of the Children Act 2004 (HM Government, 2004) limited the use of the defence of reasonable punishment so that parents and those acting in loco parentis who cause physical injury to their children can no longer use the "reasonable punishment" defence where they are charged with assaults occasioning cruelty, actual or grievous bodily harm (NSPCC, n.d.b). The defence of "reasonable punishment" is only available to parents, or others acting in loco parentis (provided they are not expressly prohibited from using physical punishment, for example in schools), where the charge is one of common assault.

Physical punishment is prohibited in all maintained and full-time independent schools, in children's homes, in local authority foster homes and early years provision. Section $5^{8}$ of the Children Act 2004 limits the defence of reasonable punishment as follows: 
(1) In relation to any offence specified in subsection (2), battery of a child cannot be justified on the ground that it constituted reasonable punishment.

(2) The offences referred to in subsection (1) are -

a. an offence under section 18 or 20 of the Offences against the Person Act 1861 (c. 100) (wounding and causing grievous bodily harm);

b. an offence under section 47 of that Act (assault occasioning actual bodily harm);

c. an offence under section 1 of the Children and Young Persons Act 1933 (c. 12) (cruelty to persons under 16).

(3) Battery of a child causing actual bodily harm to the child cannot be justified in any civil proceedings on the ground that it constituted reasonable punishment.

(4) For the purposes of subsection (3) "actual bodily harm" has the same meaning as it has for the purposes of section 47 of the Offences against the Person Act 1861.

(5) In section 1 of the Children and Young Persons Act 1933, omit subsection (7).

Effectively, physical punishment is illegal if it leaves a mark on a child or an implement (such as a cane or belt) is used to physically punish the child. However, the law in the UK does not go so far as to make all forms of physical punishment illegal and it remains legal for parents to physically punish their child, for example in the form of smacking, provided no actual bodily harm is caused (effectively, provided a mark is not left).

Section $5^{8}$ of the Children Act 2004 is clearly inconsistent with Article 19 of the United Nations Convention on the Rights of the Child, as surely any physical punishment of a child constitutes physical violence and should, within the U K legislative system (HM Government, 1988), be classified as at least Common Assault. An offence of Common Assault is committed when a person either assaults another person or commits a battery. An assault is committed when a person intentionally or recklessly causes another to apprehend the immediate infliction of unlawful force. A battery is committed when a person intentionally and recklessly applies unlawful force to another (The Crown Prosecution Service, n.d.). Complete removal of the defence of "reasonable punishment" under section $5^{8}$ has been recommended by the Equality and Human Rights Commission (2009), all four Children's Commissioners (2006), the Commission on the Family and Wellbeing of Children (2005), the National Assembly for Wales (2004), the UK Parliamentary Joint Committee on Human Rights (2003) and the House of Commons Health Select Committee (2003) (Children 
Are Unbeatable! Alliance, n.d.). It is worth reiterating that no defence of reasonableness exists in relation to adult victims.

In October 2008 the UN Committee on the Rights of the Child stated in its concluding observations on the UK that,

The committee is concerned at the failure of the State party to explicitly prohibit all corporal punishment in the home and emphasises its view that the existence of any defence in cases of corporal punishment of children does not comply with the principles and provisions of the Convention, since it would suggest that some forms of corporal punishment are acceptable.

Corporal punishment is lawful in the home in all states in the USA. State laws effectively confirm the right of parents to inflict physical punishment on their children (Global Initiative to End All Corporate Punishment of Children, 2014).

The American Academy of Pediatrics 'strongly opposes striking a child for any reason. Spanking is never recommended ...' (2015a). The AAP is also working to encourage school boards and legislatures to ban corporal punishment in the schools of all states and to adopt alternative approaches for managing student behaviour (American Academy of Pediatrics 2015b). The USA Alliance to End the Hitting of Children (n.d.), formed following a Global Summit on ending corporal punishment and promoting positive discipline, is intended to bring together individuals, groups and organisations who recognise the ineffectiveness of hitting children, the problems associated with it and the need to end the practice.

The work of Elizabeth Gershoff (2008), in conjunction with Phoenix Children's Hospital, into physical punishment in the United States is particularly interesting and relevant. Based on this work it is right to question whether it is logical that a parent can hit a child aged under 18 but if that child were to hit another adult this may be considered illegal if the child were above the age of criminal responsibility. Spanking/smacking and paddling (striking the buttocks with a wooden paddle) are not punishments of a bygone era in schools in the USA.

In the USA nearly two thirds of parents of very young children reported using physical punishment and in schools many children continue to receive physical punishment in the form of paddling (up to three strikes on the 
buttocks by a wooden paddle). During 2009 over 200,000 children are estimated to have received physical punishment in schools in the USA and although this decreased from over a quarter of a million children during the 2004-2005 school year (where Mississippi, for example, physically punished over 45,000 students and Texas physically punished over 57,000 students) (Us Department of Education, 2013) it is still a worryingly high number.

In some districts in Texas, for example, parents are asked, on enrolment of their child in school, whether physical punishment (paddling) of the child is to be allowed. Options available to parents include:

- Physical punishment of the child is allowed.

- Physical punishment of the child is not allowed.

- Physical punishment of the child is allowed but the parent must be contacted each time its use is proposed by the school (allowing the parent the final decision or, in some cases, facilitating the parent attending the school to administer the physical punishment or to administer the punishment at home).

School Principals who have delivered the allowed physical punishment in schools are acting in accordance with the policy of the organisation that they work for and in accordance with the law.

Corporal punishment in the home is lawful throughout Australia under the right of "reasonable chastisement" and similar provisions through criminal codes and the common law applicable to the relevant state or territory. In New South Wales (NSW) physical punishment by a parent or caregiver is considered unreasonable if the force is applied to a child's head or neck, or the force is applied to any part of the body in such a way as to cause, or threaten to cause, harm to the child which lasts more than a short period; in such cases the defence of "lawful correction" does not apply (Global Initiative to End All Corporate Punishment of Children, 2013). In 2010, the Nsw Government reviewed section 61AA and recommended that it be retained. In the 2012 report to the UN Committee on the Rights of the Child the Australian Government confirmed it has not taken steps to prohibit corporal punishment but indicated that there is some focus on tackling family violence. According to the Australian Human Rights Commission, 
... twenty-four years after Australia ratified the Convention on the Rights of the Child (Australian Human Rights Commission, 1990):, vulnerable groups of children and young people in this country continue to lack adequate human rights protection ... In the Commission's submission (Section 6.1), and in updated information provided by teleconference in October 2012, it is noted that the Australian Government was seeking to amend the Family Law Act 1975 (Cth) to respond more effectively to family violence and child abuse, in compliance with human rights standards, and to prioritise the safety of children in family law proceedings (Commonwealth of Australia, 2011). The Senate Committee Legal and Constitutional Affairs Committee examined these amendments and handed down their report on 22 August 2011, which supported the proposed amendments, with some minor changes. The Family Law Legislation Amendment (Family Violence and Other Measures) Act 2011 was passed by the Commonwealth Parliament in November 2011. The Act will:

- prioritise the safety of children and best interests of the child in the Family Law Act;

- remove disincentives for victims of violence and abuse to disclose this to the courts;

- reflect a more contemporary understanding of what family violence and abuse is by clearly setting out what behaviour is unacceptable, including physical and emotional abuse and the exposure of children to family violence;

- streamline the provisions relating to the reporting of family violence and child abuse to make reporting family violence simpler.

The Committee's recommendation for an education campaign about how the amendments will affect separating families has also been accepted by the Australian Government. However, the Commission's concerns about the presumption of equally shared parental responsibility, and its application, were not addressed in the Bill (Australian Law Reform Commission, 2010).

Whilst it is axiomatic that laws function better to eradicate behaviour when combined with education and supportive measures, it is difficult to see how tackling family violence will be achieved when punishment of children by physical violence remains a defence under criminal laws, particularly where the concept of reasonableness is such an ambiguous and subjective term. 
In 2013 The Paediatric \& Child Health Division of The Royal Australasian College of Physicians (RACP) issued a position statement for the purpose of protecting children.

We recognise that:

- Every child needs discipline. Discipline is an essential part of good parenting.

- While physical punishment (such as hitting or smacking a child) may appear effective in the short term, it can have adverse consequences in the long term for the child's health, particularly their behaviour and emotional wellbeing.

- There are much more effective and positive ways to provide discipline.

- A child - the most vulnerable and dependent member of our society - is still the only person in Australia whom it is legal to hit.

- The circumstances when physical punishment is likely to be used place a child at risk of an unintended escalation to serious physical assault.

The RACP believes that physical punishment is an outdated practice. It fails to recognise the human rights of the child. The purpose of this paper is to clarify paediatricians' position on physical punishment of children, to contribute to public discussion, and to promote positive non-violent discipline which will provide each Australian child with the best opportunity for future health and well-being ... We consider it important to resolve the inconsistency in Australian law which allows only children to be hit. We acknowledge this may take time to become accepted and instituted but believe the process should be commenced.

The continued legality of physical punishment of children in the UK, USA and Australia is a serious violation of the UN Convention on the Rights of the Child. Until all three countries grapple with the reality and make it explicitly clear, in law, that physical punishment of children is prohibited in all circumstances, not only is each country non-compliant with the UN Convention on the Rights of the Child but their children are not afforded the protection from physical violence that they deserve and need.

\section{Complications for Clinicians}

In 2010, there were over 25.5 million emergency department (ED) visits for children younger than 18 years in the USA (Wier et al., 2013). Over 3.5 million 
children aged o to 16 years are seen in UK EDs each year (Royal College of Paediatrics and Child Health, 2007) and in 2012 to 2013, 1,442,860 children (aged o to 14 years) were seen in Australian EDs (Australian Institute of Health and Welfare, 2013). Clinicians working in those emergency departments have a crucial role to play in identifying those children who may have suffered from, or who are at risk of, significant harm. Clinicians working in emergency medicine are ideally placed to recognise some of the early warning signs that a child may have been maltreated or may be at risk of maltreatment so that they can take steps to safeguard those children attending their EDs from further abuse and neglect. Furthermore, government guidance specifically relating to the identification and support of children who might have been trafficked makes clear that all practitioners who come into contact with children and young people in their everyday work need to be able to recognise children who have been trafficked (Department for Education and the Home Office, 2011) and be competent to act to support and protect these children from harm.

Given the risk factors for parents who are more likely to use physical punishment on their children, given the increased risk of further episodes of physical punishment when used by a parent (Strassberg et al., 1994) and given the risks that this poses to the children concerned, professionals need to be vigilant to look out for signs that any such punishment was not reasonable, or to consider carefully whether the risks of a particular situation are significant enough that the child in question is at risk of significant harm and that such harm is greater than the harm already caused by an outdated law which permits parents physically to punish their children at the current time.

Since the evidence against physical punishment of children appears to outweigh evidence to the contrary, the implications for health care professionals who are committed to evidence-based practice are fairly obvious: when working with families and communities, advice should be concentrated on developing interventions that empower parents to choose not to smack by helping them to develop effective strategies for dealing with stress and by raising selfesteem (Smith, 2003; Taylor and Redman, 2004).

Regardless of whether there is a statistically significant association between deaths from child maltreatment and the legal corporal punishment situation in a particular country or state, if there is to be a reduction in the number of cases of child death from child abuse and the number of cases of child maltreatment, given the role that society has in protecting those children, this must begin from a stand-point of taking the moral high ground which is that it is unacceptable to punish children physically, whatever the circumstances, and that there are much more effective and appropriate discipline methods to administer. 
In addition, whilst physical punishment is lawful it makes it difficult to identify where children are routinely abused and children who are largely well cared for. It is far better to prohibit physical punishment in all circumstances and leave decisions on whether or not to prosecute for prosecutorial discretion or guidelines, and whether actions were unlawful, and appropriate levels of sentencing, to judicial discretion.

\section{Conclusion}

The brief examination of international law in this article has exposed that the purpose of internationally accepted principles is to protect children from violence. This is undermined by domestic legislation which condones family violence in the name of punishment of children and creates insuperable difficulties for clinicians trying to identify a child at risk from abusive parents from a parent who is otherwise caring but had a momentary loss of control. The consequence is that the continuation of a defence of lawful chastisement allows for the abuse of children to remain hidden.

In addition, to discipline children through physical violence merely serves to educate them that such violence is accepted and encouraged by society which may teach them to behave in this way as they grow older. We question whether this is a society in which the majority of people would wish to live in the future. In addition to changing the law, raising awareness (so that people understand the nature and scale of child abuse, the behaviour of offenders, early warning signs and the effects on children), changing attitudes (dispelling the myths so people are more willing to talk about abuse and see its prevention as part of all adults' responsibilities), changing behaviour (so that people take appropriate action to prevent abuse and to seek help if they are worried about themselves or others) and developing a public health approach (as child abuse requires a large-scale systematic approach to prevention) are all ways that the community could work together more collaboratively to prevent child abuse (Reynolds, 2007).

Moves to prevent family violence are progressive but the position of a society where physical punishment of children is permitted yet child abuse is forbidden is not a tenable one. Reducing the number of cases of child abuse must begin with a clear message from society that physical punishment of children, whatever the circumstances, is unacceptable.

Either society must come to that conclusion itself and demand a change in the law or, if society cannot do this in a timely fashion, the law-makers in that society, in the form of Parliamentarians, must take the brave decision that, 
despite some opposing public opinion, the situation is serious enough to introduce aspirational legislation to remove justifications for physical punishment of children with the aim of modifying behaviour within society.

Although the law is best seen as enforcing what a society is prepared to accept as appropriate conduct, and whilst caution must be exercised when introducing aspirational legislation which may not have the immediate support of a significant number of members of society, the situation for children at risk of significant harm is serious enough to warrant ratification of international instruments and legislative change in all our considered jurisdictions to make explicitly clear that there is no defence of "reasonable punishment" and that any corporal or physical punishment of a child, aged under 18 years of age, is strictly prohibited in law.

\section{References}

Afifi, T.O., Mota, N.P., Dasiewicz, P., MacMillan, H.L., Sareen, J., "Physical punishment of children and mental disorders: Results from a nationally representative us sample", Pediatrics 2012 (130(2)) 184-192.

American Academy of Child and Adolescent Psychiatry, Child Maltreatment and Violence Committee, Policy Statement on Corporal Punishment (Washington, DC: American Academy of Child and Adolescent Psychiatry, 3o July 2012): http:// www.aacap.org/aacap/Policy_Statements/2012/Policy_Statement_on_Corporal _Punishment.aspx.

American Academy of Pediatrics, Spanking Linked to Mental Illness (Chicago: AAP, 2 July 2012): http://www.aap.org/en-us/about-the-aap/aap-press-room/Pages/ Spanking-Linked-to-Mental-Illness.aspx.

American Academy of Pediatrics, Where We Stand: Spanking (Elk Grove Village, IL: American Academy of Pediatrics, 2015a): http://www.healthychildren.org/English/ family-life/family-dynamics/communication-discipline/Pages/Where-We-Stand -Spanking.aspx.

American Academy of Pediatrics, School Discipline (Elk Grove Village, IL: American Academy of Pediatrics, 2015b): https:/www.healthychildren.org/English/ages -stages/gradeschool/school/Pages/School-Discipline.aspx.

American Humane Association, Child Protection Position Statements (Washington, DC:

American Humane Association, 2009): http://www.americanhumane.org/assets/ pdfs/about/position-statements/children-position.pdf.

American Humane Association, How One Girl's Plight Started the Child-Protection Movement (Washington, DC: American Humane Association, n.d.): http://www .americanhumane.org/about-us/who-we-are/history/mary-ellen-wilson.html. 
Australian Human Rights Commission, Convention on the Rights of the Child (Sydney: Australian Human Rights Commission, 1990): https:/www.humanrights.gov.au/ convention-rights-child.

Australian Institute of Family Studies, Child abuse and neglect statistics: Resource Sheet 2015 (Melbourne: AIFs, 2016): https://www3.aifs.gov.au/cfca/publications/ child-abuse-and-neglect-statistics.

Australian Institute of Family Studies, CFCA Resource Sheet August 2014 (Melbourne: AIFS, 2014): https://www3.aifs.gov.au/cfca/publications/child-deaths-abuse-and -neglect.

Australian Institute of Health and Welfare, Australian Hospital Statistics 2012-13, Emergency department care (Canberra: AIHF, 2013): http://www.aihw.gov.au/WorkArea/ DownloadAsset.aspx?id=60129544764.

Australian Institute of Health and Welfare, Child protection Australia 2012-13 (Canberra: AIHW, released 25 2014): http://www.aihw.gov.au/publication-detail/? id $=60129547965$.

Australian Law Reform Commission, Family Violence - A National Legal Response (Canberra: Australian Law Reform Commission, 2010): http://www.alrc.gov.au/ sites/default/files/pdfs/publications/ALRC114_WholeReport.pdf.

Barkin, S., Scheindlin, B., Ip, E.H., Richardson, I., Finch, S., "Determinants of parental discipline practices: A national sample from primary care practices", Clinical Paediatrics 2007 (46(1)) 64-69.

Baumrind, D., Larzelere, R. E., Cowan, P. A., "Ordinary physical punishment: is it harmful? Comment on Gershoff (2012)", Psychological Bulletin $2012(128(4)) 580-590$ and 602-611.

Bell, T., Romano, E., "Opinions about child corporal punishment and influencing factors", Journal of Interpersonal Violence 2012; 27(11): 2208-2229.

Benjet, C., Kazdin, A. E., "Spanking children: the controversies, findings and new directions", Clinical Psychology Review 2003 (23) 197-224.

Bitensky, S. H., "Spare the Rod, Embrace Our Humanity: Toward a New Legal Regime Prohibiting Corporal Punishment of Children", University of Michigan Journal of Law Reform 1997-1998 (31) 353.

Bitensky, S. H., Corporal Punishment of Children: A Human Rights Violation (Ardsley, New York: Transnational Publishers, 2006).

"Book of Proverbs (13:24)", The King James (AV) Version of the Bible.

Bower-Russa, M. E., Knutson, J. F., Winebarger, A., "Disciplinary history, adult disciplinary attitudes and risk for abusive parenting", Journal of Community Psychology 2001 (29) 219-240.

Children Are Unbeatable! Alliance, Support in the UK for legal reform to ban physical punishment and remove the "reasonable punishment" defence (London: Children Are Unbeatable! Alliance, n.d.): http://www.childrenareunbeatable.org.uk/current -position/support-in-the-uk.html. 
Children's Hospital of Eastern Ontario, Joint Statement on Physical Punishment of Children and Youth (Ottawa: Children's Hospital of Eastern Ontario (CHEO), 2012): http://www.cheo.on.ca/en/physicalpunishment.

Committee on Psychosocial Aspects of Child and Family Health, Guidance for Effective Discipline 1998 (10(4)): http://pediatrics.aappublications.org/content/101/4/723.

Committee on the Rights of the Child, General Comment No. 8 (2006): The right of the child to protection from corporal punishment and/or cruel or degrading forms of punishment (articles 1, 28(2) and 37, inter alia)(CRC/C/GC/8) (Geneva, Switzerland: United Nations, 2006).

Commonwealth of Australia, Family Law Legislation Amendment (Family Violence and Other Measures) Bill 2011: http://www.austlii.edu.au/au/legis/cth/bill_em/ fllavaomb2011623/memo_o.html.

Cook, E., Kopko, K., Why spanking should be discouraged (Ithaca, NY: Cornell University, 2014): https://www.human.cornell.edu/pam/outreach/parenting/parents/ upload/Spanking-Research-Brief.pdf.

Council of Europe, Europe-wide ban on corporate punishment of children (Strasbourg: Council of Europe, 2004): http://assembly.coe.int/nw/xml/XRef/Xref-XML2HTML -en.asp?fileid $=17235 \&$ lang=en.

Crandall, M., Chiu, B., Sheehan, K., "Injury in the first year of life: risk factors and solutions for high-risk families", Journal of Surgical Research 2006 (133) 7-10.

Day, R. D., Peterson, G.W., McCracken, C., "Predicting spanking of younger and older children by mothers and fathers," Journal of Marriage and the Family 1998 (6o) 79-94.

Deater-Deckard, K., Landsford, J. E., Dodge, K. A., Pettit, G. S., Bates, J. E., “The development of attitudes about physical punishment: an 8-year longitudinal study",Journal of Family Psychology 2003 (17(3)) 351-360.

Department for Education and the Home Office, Safeguarding Children Who May Have Been Trafficked (London: HM Government, October 2011).

Durrant, J. E., Ensom, R. and Coalition on Physical Punishment of Children and Youth (2004) Joint Statement on Physical Punishment of Children and Youth (Ottawa: Coalition on Physical Punishment of Children and Youth, 2004): http://www.cheo.on.ca/ uploads/advocacy/joint_statement_e.pdf.

Evans, S. Z., Simons, L. G., Simons, R. L., "The effect of corporal punishment and verbal abuse on delinquency: mediating mechanisms", Journal of Youth and Adolescence $2012(41(8))$ 1095-1110.

Ferguson, C. J., "Spanking, corporal punishment and negative long-term outcomes: a meta-analytic review of longitudinal studies", Clinical Psychology Review 2013 (33(1)) 196-208.

Finkelhor, D., Turner, H. A., Ormond, R., Hamby, S. L., "Violence, crime, and abuse exposure in a national sample of children and youth: an update", JAMA Pediatrics 2013 (167(7)), 614-62. doi:10.1001/jamapediatrics.2013.42. 
Gagne, M. H., Tourigny, M., Joly, J., Pouliot-Lapointe, J., "Predictors of adult attitudes toward corporal punishment of children", Journal of Interpersonal Violence 2007 (22(10)) 1285-1304.

Gámez-Gauadix, M., Straus, M. A., Carrobles, J. A., Munoz-Rivas, M. J., Almendros, C., "Corporal punishment and long-term behavior problems: the moderating role of positive parenting and psychological aggression", Psicothema 2010 (22(4)) 529-536.

Gershoff, E. T., Miller, P. C., Holden, G. W., "Parenting influences from the pulpit: Religious affiliation as a determinant of parental corporal punishment", Journal of Family Psychology 1999 (13) 307-320.

Gershoff, E.T., Report on Physical Punishment in the United States: What Research Tells Us About Its Effects on Children (Columbus, Ohio: Center for Effective Discipline, 2008) http://www.nospank.net/gershoff.pdf.

Giles-Sims, J., Straus, M. A., Sugarman, D. B., "Child, maternal and family characteristics associated with spanking”, Family Relations 1995 (44) 170-176.

Global Initiative to End All Corporal Punishment of Children, Report Update April 2013: http://www.endcorporalpunishment.org/.

Global Initiative to End All Corporal Punishment of Children, Report 2014: http://www .endcorporalpunishment.org/pages/progress/reports/usa.html.

Global Initiative to End All Corporal Punishment of Children, States which have prohibited all corporal punishment (n.d.): http://www.endcorporalpunishment.org/ progress/prohibiting-states/.

Global Initiative to End All Corporal Punishment of Children: http://www.end corporalpunishment.org/.

Hain, R. D. W., "Occasional smacking does no harm”, вMJ 3 June 2000 (320) 1539.

HM Government, Section 58 of the Children Act 2004 (London: HM Government, 2004): http://www.legislation.gov.uk/ukpga/2004/31/section/58.

HM Government, Section 39, Criminal Justice Act 1988 (London: HM Government, 1988): http://www.legislation.gov.uk/ukpga/1988/33/section/39.

HM Government, Working Together to Safeguard Children (London: HM Government, 2013).

Horn, I. B., Joseph, J. G., Cheng, T. L., "Nonabusive physical punishment behavior among African-American Children: a systematic review", Journal of the National Medical Association 2004 (96(9)) 1162-1168.

Human Rights Watch, Banning corporal punishment: International human rights law and us constitutional standards (New York: HRw, 2008a): http://www.hrw.org/reports/2008/uso808/11.htm.

Human Rights Watch, Corporal Punishment in Us Public Schools (New York: HRW, 2008b): https://www.hrw.org/reports/2008/uso808/3.htm.

INTERPOL, Appropriate terminology (n.d.): www.interpol.int/Crime-areas/Crimes -against-children/Appropriate-terminology. 
Kiong, T. C., Elliott, J. M., Tan, P. M. E. H., Public perceptions of child abuse and neglect in Singapore, Research monograph number 1 (Singapore: Singapore Children's Society, December 1996). IS BN 981-00-8317-3.

Kempe, C. H., Silverman, F. N., Steele, B. F., Droegemueller, W., Silver, H. K, "The battered-child syndrome", Journal of the American Medical Association 1984 (251(24)), 3288-3294.

Larzelere, R. E., "Weak evidence for a smacking ban", BMJ 3 June 2000 (320) 1538-1539.

Lee, Y., Svevo-Cianci, K. A., "Twenty years of the Convention on the Rights of the Child: Achievements and challenges for child protection", Child Abuse and Neglect 2009 (33) $767-770$.

National Association of Pediatric Nurse Practitioners, NAPNAP Position Statement on Corporal Punishment (Cherry Hill, NJ: National Association of Pediatric Nurse Practitioners, 2011): http://nospank.net/pednurse.pdf.

National Association of Social Workers, Social work speaks: National Association of Social Workers policy statements, 2015-2017 (Washington, D.C: NASW Press, 2015, 10th edn.): http://www.nasw-md.org/?page $=100$.

NSPCC, Every Childhood is worth fighting for (London: NSPCC, n.d.a): http://www .nspcc.org.uk/what-we-do/the-work-we-do/priorities-and-programmes/physical -abuse/physical-abuse-theme/physical-abuse_wda86211.html.

NSPCC, PhysicalAbuse:Legislation Policy and Guidance (London: NSPCC, n.d.b): https:// www.nspcc.org.uk/preventing-abuse/child-abuse-and-neglect/physical-abuse/ legislation-policy-guidance/.

Office for National Statistics, "Chapter 2 - Homicide" Crime and Justice (London: Office for National Statistics, 2014): http://www.ons.gov.uk/ons/dcp171776_35226o .pdf.

People of the United Methodist Church, Discipline Children Without Corporal Punishment (United Methodist Communications, 2012): http://www.umc.org/ what-we-believe/discipline-children-without-corporal-punishment.

Pinheiro, P., World Report on Violence Against Children (New York: United Nations, 2006): http://www.unicef.org/lac/full_tex(3).pdf.

Poulsen, A., "The long term impact of corporal punishment", The Age, 10 May 2015 (Melbourne: Fairfax): http://www.theage.com.au/comment/the-long-term-impact -of-corporal-punishment-20150505-ggurdb.html.

Radford, L., Corral, S., Bradley, C., Fisher, H., Bassett, C., Howat, N., Collishaw, S., Child abuse and neglect in the UK today (London: NSPCC; 2011): https://www.nspcc.org.uk/ globalassets/documents/research-reports/child-abuse-neglect-uk-today-research -report.pdf.

Regalado, M., Sareen, H., Inkelas, M., Wissow, L. S., Halfon, N., "Parents' discipline of young children: Results from the National Survey of Early Childhood Health", Pediatrics $2004(113(6 / 2)) 195^{2-1958 . ~}$ 
Reynolds, M., "A public health approach for preventing child sexual abuse", Community Practitioner 2007 (80(2)) 14-15.

Rice, H., "Critics decry judge's order of courtroom paddling", Houston Chronicle, 8 May 2001 (Texas: Houston Chronicle).

Rice, H., "Justice of Peace defends boy's courtroom paddling”, Houston Chronicle, 7 May 2001 (Texas: Houston Chronicle).

Roberts, M. W., Powers, S. W., "Adjusting chair time-out enforcement procedures for oppositional children", Behavior Therapy 1990 (21) 257-271.

Rowland, A. G., Living on a Railway Line (Salford: The University of Salford, The Pennine Acute Hospitals NHs Trust and The Winston Churchill Memorial Trust, 2014): http://www.wcmt.org.uk/users/andrewrowland2014.

Royal College of Paediatrics and Child Health, Position Statement on Corporal Punishment (London: Royal College of Paediatrics and Child Health, 2009): http://www .rcpch.ac.uk/sites/default/files/asset_library/Policy\%2oand\%2oStandards/ Policy\%2oDocuments/Corporal\%2oPunishment\%2oPolicy\%2oNovog.pdf.

Royal College of Paediatrics and Child Health, Services for Children in Emergency Departments (London: RСРCH, 2007): http://rcpch.lpl-uk.com/pubdetail. php?StockID=Xo28.

Simons, L. G., Simons, R. L., Su, X., "Consequences of corporal punishment among African Americans: the importance of context and outcome", Journal of Youth and Adolescence 2013 (42(8)) 1273-1285.

Smith, S., "Is smacking abusive? Does it matter?", Community Practitioner 2003 (76) 304-307.

Strassberg, Z., Dodge, K. A., Pettit, G. S., Bates, J. E., "Spanking in the home and children's subsequent aggression towards kindergarten peers", Development and Psychopathology $1994(6(3))$ 445-461.

Straus, M. A., Beating the devil of them: Corporal punishment in American families (Piscataway, New Jersey: Transaction Publishers, 2001, $2^{\text {nd }}$ edn.).

Taylor, J., Redman, S.. "The smacking controversy: what advice should we be giving parents?", Journal of Advanced Nursing 2004 (46(3)) 311-318.

The Crown Prosecution Service, Offences against the person incorporating standard charging (London: The Crown Prosecution Service, n.d.): https://www.cps.gov.uk/ legal/1_to_o/offences_against_the_person/\#a07.

The New York Society for the Prevention of Cruelty to Children, History: 1870-1874: The Catalyst (New York: New York Society for the Prevention of Cruelty to Children, n.d.): http://www.nyspcc.org/about/history/.

Triple P International, The Triple P - Positive Parenting Program (Brisbane: University of Queensland, n.d.): http://www.triplep.net/glo-en/home/. 
United Nations, Convention on the Rights of the Child(London:UNICEF UK,1989): http:// www.unicef.org.uk/Documents/Publication-pdfs/UNCRC_PRESS20og1oweb.pdf.

U.s. Alliance to End the Hitting of Children (n.d.): http://www.endhittingusa.org/.

U.s. Department of Education, U.s. Department of Education Releases Estimated State and National Figures from 2009-10 Civil Rights Data Collection (US Dept. of Education Office for Civil Rights, 2013): http://www.ed.gov/blog/2013/12/u-s-department-of -education-releases-estimated-state-and-national-figures-from-2009-10-civil -rights-data-collection/.

U.s. Department of Health \& Human Services, Administration for Children and Families, Administration on Children, Youth and Families, Children's Bureau, Child maltreatment 2014 (Washington, DC: U.S. Department of Health \& Human Services, 2016): http://www.acf.hhs.gov/sites/default/files/cb/cm2014.pdf.

Vlasis-Cicvaric, I., Prpic, I., Boban, M., Korotaj, Z., “Children's reflections on corporal punishment", Public Health 2007 (121 (3)) 220-222.

Whiting, L., Whiting, M., Whiting, T., Whiting, L., "Smacking a family perspective", Paediatric Nursing 2004 (16(8)) 26-28.

Wier, M., Hao Yu, Owens, P. L., Washington, R., Overview of Children in the Emergency Department, 2010 (Rockville, MD: Agency for Healthcare Research and Quality, 2013): http://www.hcup-us.ahrq.gov/reports/statbriefs/sb157.pdf.

Wilson, D. R., Lyman, R. D., "Time-out in the treatment of childhood behaviour problems: implementation and research issues", Child \& Family Behavior Therapy 1982 (4) $5^{-20 .}$

Wissow, L. S., "Ethnicity, income, and parenting contexts of physical punishment in a national sample of families with young children", Child Maltreatment 2001 (6) 118-129. 